Edutech, Tahun 13, Vol.1, No.1, Februari 2014

\title{
PENGGUNAAN KEDWIBAHASAAN SEBAGAI MEDIA KOMUNIKASI PENJUAL ASESORIS TOKO ROCK STUFF PLAZA PARAHYANGAN BANDUNG
}

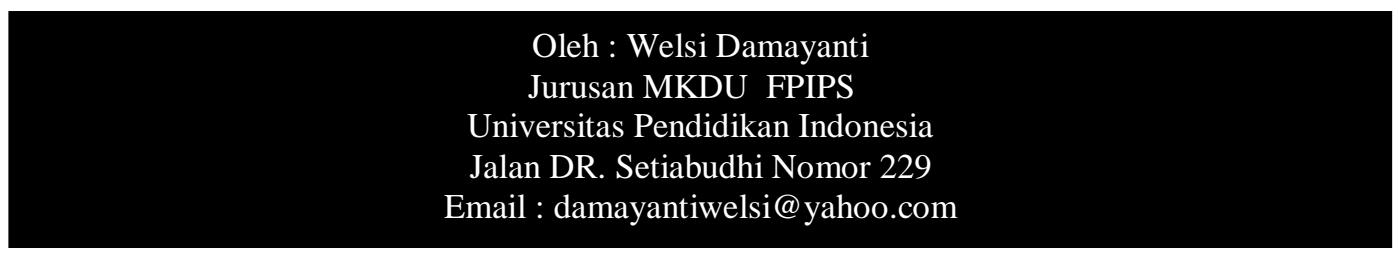

Abstract.Humans are social creatures humans would therefore need to master the various languages that relate to other human beings or to communicate within the community. Kedwibahasaan term can also be used for the community when the community in the life of a language is to use two or more languages alternately. This can happen if the people that there are two (or more) languages. In such circumstances there is also in Indonesia because in addition to Indonesian as the language of the country, there is also the local language of each tribe were several hundred in number. The research analyzes the habit of using a second language (B2) accessories sellers in Rock Stuff Accessories store this type of qualitative research using descriptive methods. The result is very attractive to researchers because of its being quite challenging discussion is about the habit of using a second language by the seller from Padang in store Rock Stuff Accessories. They always try to cater to buyers who came from Bandung using the language. All that for smooth and familiarity between sellers and buyers.

Keywords: communication, bilingual, second language

Abstrak, Manusia adalah makhluk sosial karena itu manusia tentu perlu mengusai berbagai bahasa yang berhubungan dengan manusia lain atau berkomunikasi dalam masyarakat. Istilah kedwibahasaan dapat juga dipakai untuk masyarakat bila suatu masyarakat dalam kehidupan berbahasanya menggunakan dua bahasa atau lebih secara bergantian. Hal ini dapat terjadi jika dalam masyarakat itu ada dua (atau lebih) bahasa. Keadaan seperti itu terdapat pula di Indonesia sebab di samping bahasa Indonesia sebagai bahasa negara, terdapat juga bahasa daerah dari setiap suku bangsa yang beratus-ratus jumlahnya. Penelitian analisis kebiasaan menggunakan bahasa kedua (B2) para penjual asesoris di toko Rock Stuff Asesoris ini berjenis penelitian kualitatif dengan menggunakan metode deskriptif. Hasil penelitian ini sangat menarik bagi peneliti karena yang menjadi pembahasannya cukup menantang yaitu tentang kebiasaan menggunakan bahasa kedua oleh penjual yang berasal dari Padang di toko Rock Stuff Asesoris. Hasil penelitian ini adalah adanya kedwibahasaan pada situasi jual beli yang terjadi di kota Bandung. Mereka selalu berusaha melayani pembeli yang berasal dari Bandung dengan menggunakan bahasa Sunda. Semua itu demi kelancaran dan keakraban antara penjual dan pembeli.

Kata kunci: komunikasi, dwibahasa, bahasa kedua

\section{A. PENDAHULUAN}

Bahasa merupakan alat untuk masyarakat. Bahasa tidak hanya untuk

berkomunikasi yang digunakan oleh berinteraksi dua arah tetapi juga untuk 
Edutech, Tahun 13, Vol.1, No.1, Februari 2014

menyampaikan perasaan kepada seseorang atau orang banyak. Manusia adalah makluk sosial yang selalu menggunakan bahasa dalam kehidupannya. Tingkat sosial suatu masyarat juga menggambarkan bahasa yang digunakannya.

Manusia adalah makhluk sosial karena itu manusia tentu perlu mengusai berbagai bahasa yang berhubungan dengan manusia lain atau berkomunikasi dalam masyarakat. Komunikasi merupakan sesuatu hal yang biasa dilakukan oleh manusia. Sejak dulu komunikasi digunakan oleh orang-orang terdahulu walaupun belum sadar bahwa kegiatan tersebut disebut dengan komunikasi. Komunilasi yang dilakukan itu tentunya ada alat yang digunakan sebagai medianya. Alat yang dimaksud ialah bahasa. Banyak negara-negara tidak hanya menggunakan satu bahasa saat mereka berkomunikasi. Ini membuktikan bahwa masyarakat di Indonesi khususnya dan di dunia umumnya banyak menggunakan bahasa sebagai alat komunikasi mereka.
Menurut Nababan, dkk (1992: 7) mengungkapkan bahwa kemampuan memakai dua bahasa atau lebih dan pemakaian kedua bahasa itu secara bergantian disebut kedwibahasaan. Istilah kedwibahasaan dapat juga dipakai untuk masyarakat bila suatu masyarakat dalam kehidupan berbahasanya menggunakan dua bahasa atau lebih secara bergantian. Hal ini dapat terjadi jika dalam masyarakat itu ada dua (atau lebih) bahasa. Keadaan seperti itu terdapat pula di Indonesia sebab di samping bahasa Indonesia sebagai bahasa negara, terdapat juga bahasa daerah dari setiap suku bangsa yang beratusratus jumlahnya. Pada umumnya, bangsa Indonesia sejak kecil dididik dan dibesarkan dalam bahasa daerah yang merupakan bahasa ibu bagi mereka sehingga dalam kehidupan berbahasa pengaruh bahasa daerah itu selalu menyertai cara dan gaya berbahasa mereka.

Dalam hal bahasa, ciri linguistik merupakan kreteria pembatas yang paling penting untuk keanggotaan etnik. Kita sering membedakan suku 
Edutech, Tahun 13, Vol.1, No.1, Februari 2014

bangsa seseorang karena bahasa atau berdasarkan bahasa. Tetapi rumusan kita sering kurang tepat. Misalnya, kita tidak begitu tepat kalau mengatakan orang Bali berbahasa Bali dan orang Minang berbahasa Minang; lebih baik kita mengatakan penutur asli bahasa Bali biasanya dianggap orang Bali (paling tidak oleh orang Bali yang lain) apapun kebangsaan mereka (Sumarsono, 2007: 71). Berdasarkan hal di atas, maka peneliti merasa tertarik untuk mengamati penggunaan bahasa lebih dari satu bahasa sebagai alat komunikasi oleh para pedagang yang tentunya akan bertemu dengan pembeli yang berbeda daerah. Berbeda daerah tentu akan berbeda bahasa. Komunikasi dalam perdagangan ini akan sangat menarik dengan adanya penggunaan bahasa yang lebih dari satu dalam satu waktu. Bahasa pertama merupakan bahasa ibu yang kita peroleh berdasarkan asal daerah kita, sedangkan bahasa kedua merupakan bahasa yang kita peroleh dari lingkungan. Pada penelitian ini para penjual merupakan orang padang yang tentunya bahasa pertamanya adalah bahasa Minang. Mereka akan menggunakan bahasa kedua ialah bahasa Sunda karena berada di kota Bandung. Tentunya mayoritas pembeli di kota Bandung merupakan orang Sunda yang seringkali menggunakan bahasa Sunda sebagai alat komunikasinya. Penjual yang bukan berasal dari kota Bandung tentu dituntut untuk bisa menggunakan bahasa setempat. Oleh karena itu, peneliti tertarik untuk mengetahui kebiasaan menggunakan bahasa kedua dari para penjual yang merupakan orang asli dari Padang.

\section{Rumusan Masalah}

Berdasarkan latar belakang masalah di atas, masalah dalam penelitian ini dapat dirumuskan seperti berikut ini. Rumusan yang dimaksud adalah "Kebiasaan Menggunakan Bahasa Kedua (B2) oleh Para Penjual Asesoris di Toko Rock Stuff Asesoris."

\section{Tujuan Penelitian}

Adapun tujuan penelitian ini adalah (1) untuk mendesripsikan kebiasaan menggunakan bahasa kedua para penjual asesoris di toko Rock Stuff Asesoris, (2) untuk mengetahui 
Edutech, Tahun 13, Vol.1, No.1, Februari 2014

situasi apa saja kebiasaan penelitiannya sudah jelas yaitu manusia menggunakan bahasa kedua para sebagai pengguna bahasa. penjual asesoris di toko Rock Stuff

\section{Landasan Teori}

Asesoris, (3) sejauh mana kebiasaan

Ilmu bahasa dalam masyarakat menggunakan bahasa kedua para sangat penting dalam kelompok sosial, penjual asesoris di toko Rock Stuff dari kelompok sosial biasa yang kecil Asesoris.

\section{Metode Penelitian}

Penelitian analisis kebiasaan dari beberapa ratus orang-orang sampai bagi keseluruhan negara. Jika semua menggunakan bahasa kedua (B2) para penjual asesoris di toko Rock Stuff Asesoris ini berjenis penelitian kualitatif dengan menggunakan metode deskriptif. Sehubungan dengan tujuan penelitian ini, yakni mendeskripsikan kebiasaan menggunakan bahasa kedua (B2) oleh para penjual asesoris di toko Rock Stuff Asesoris, maka sangat tepat digunakan metode ini.

orang dalam kelompok berbicara persisnya sama dengan semua orang selain dalam kelompoknya, disana ada ketidakbenaran seperti ilmu bahasa sosial dalam masyarakat. Bahasa digunakan oleh orang bukan hanya untuk berbagi perasaan dan pemikiran mereka dengan orang lain, tetapi mereka memanfaatkan bahasa untuk mengungkapkan dan menggambarkan hubungan sosial mereka dengan orang-

Dalam kaitannya dengan orang dalam berkomunikasi. Baik pendekatan kualitatif, penelitian orang disekitarnya maupun dimana kualitatif tidak meneliti lahan kosong, saja. tetapi menggalinya. Pengguna banyak

Negara-negara di dunia banyak bahasa merupakan lahan yang akan menjadikan bahasa sebagai identitas digali. Penggalian ini dilakukan dengan kerja. Sejumlah negara-negara tidak cara mendeskripsikan, mengolah, dan menjadi yang luar biasa dalam menganalisis data yang telah ada di menggunakan lebih dari satu bahasa lokasi yang dijadikan wadah bahkan anak-anak menguasai satu atau penelitian. Yang mana objek dua bahasa. Dalam rangka memahami 
Edutech, Tahun 13, Vol.1, No.1, Februari 2014

penggunaan banyak bahasa yang Hovland dalam Effendy (2011: 9) berarti untuk suatu masyarakat, akan komunikasi adalah proses mengubah menjadi sangat menolong untuk perilaku orang lain. Tapi seseorang mempunyai konsep di dalam pikiran.

Di tingkat individu, pengguna banyak bahasa bertindak sebagai sumber daya interaksi untuk pembicara banyak bahasa. Secara khas, masyarakat banyak bahasa cenderung menugaskan tugas yang berbeda untuk perbedaan bahasa atau jenis bahasa. Masyarakat aneka bahasa atau masyarakat multilingual adalah masyarakat yang mempunyai beberapa bahasa. Masyarakat demikian terjadi karena beberapa etnik ikut membentuk masyarakat, sehingga dari segi etnik bisa dikatakan sebagai masyarakat majemuk. Demikian pula masyarakat ini sekarang menggejala di dunia, menjadi universal. Kebanyakan bangsa di dunia memiliki lebih dari satu bahasa yang digunakan sebagai bahasa ibu dalam wilayah yang dihuni bangsa itu, bahkan bangsa Indonesia mempunyai lebih dari 500 bahasa.

Penggunaan bahasa sangat berperan sebagai alat komunikasi untuk interaksi dengan orang lain. Menurut akan mengubah sikapnya, pendapat, ataupun perilakunya apabila komunikasinya memang komunikatif. Lasswell dalam Effendy (2011: 9) mengatakan bahwa cara yang baik untuk menjelaskan komunikasi ialah menjawab pertanyaan: Who Says What In Which Channel To Whom With What Effect? Komunikasi meliputi lima unsur sebagai jawaban dari pertanyaan yang diajukan itu yakni komunikator, pesan, media, komunikan, dan efek. Jadi, komunikasi adalah proses penyampaian pesan oleh komunikator kepada komunikan melalui media yang menimbulkan efek tertentu.

Komunikasi merupakan hal yang menjadi rutinitas dalam kehidupan manusia. Setiap waktu dalam segala aktifitas manusia pasti akan melakukan komunikasi. Apapun bentuk aktifitasnya. Ini karena manusia adalah makhluk sosial yang ingin berhubungan dengan manusia lain dan saling membutuhkan. Rasa ingin tahu 
Edutech, Tahun 13, Vol.1, No.1, Februari 2014

manusia itu yang membuat mereka dalam hal terjadi perbedaan pendapat melakukan komunikasi.

mengenai hal-hal yang menyangkut

Menurut Suwatno (2010: 3) orang banyak, (5) pendidikan, yakni Komunikasi merupakan hal yang membuka kesempatan untuk sangat fundamental dalam kehidupan memperoleh pendidikan secara luas, manusia. Keberhasilan dan kegagalan baik untuk pendidikan formal maupun seseorang dalam mencapai sesuatu informal, (6) memajukan kebudayaan, yang diinginkan termasuk bidang media massa menyebarkan hasil-hasil perdagangan ditentukan oleh kebudayaan melalui aneka program kemampuan dalam berkomunikasi. siaran atau penerbitan buku, (7) Adapun fungsi komunikasi secara hiburan, media massa telah menyita menyeluruh yaitu: (1) sebagai banyak waktu luang dari semua informasi, yakni kegiatan golongan usia dengan difungsikannya mengumpulkan, menyimpulkan data, media komunikasi sebagai alat fakta dan pesan, opini dan komentar, penghibur dalam rumah tangga, dan (8) sehingga orang bisa mengetahui integrasi, menjebatani perbedaan keadaan yang terjadi di luar dirinya, (2) antarsuku bangsa maupun antarbangsa sosialisasi, yakni menyediakan dan dalam upaya memperkokoh hubungan mengajarkan ilmu pengetahuan, dan pemerataan informasi.

bagaimana bersikap sesuai dengan Bahasa merupakan suatu sistem nilai-nilai yang ada, serta bertindak komunikasi yang mempergunakan sebagai anggota masyarakat secara simbol-simbol vokal (bunyi ujaran) efektif, (3) motivasi, yakni mendorong yang bersifat arbitrer, yang dapat seseorang untuk mengikuti kemajuan diperkuat dengan gerak-gerik badaniah orang lain melalui apa yang mereka yang nyata. Ia merupakan simbol baca, lihat dan dengar melalui media karena rangkaian bunyi yang dihasilkan massa, (4) bahan diskusi, yakni oleh alat ucap manusia harus diberikan menyediakan informasi sebagai bahan makna tertentu pula. Simbol adalah diskusi untuk mencapai persetujuan tanda yang diberikan makna tertentu, 
Edutech, Tahun 13, Vol.1, No.1, Februari 2014

yaitu mengacu kepada sesuatu yang dapat diserap oleh panca indra. Berarti bahasa mencakup dua bidang, yaitu vokal yang dihasilkan oleh alat ucap manusia, dan arti atau makna yaitu hubungan antara rangkaian bunyi vokal dengan barang atau hal yang diwakilinya,itu. Bunyi itu juga merupakan getaran yang merangsang alat pendengar kita (yang diserap oleh panca indra kita, sedangkan arti adalah isi yang terkandung di dalam arus bunyi yang menyebabkan reaksi atau tanggapan dari orang lain). Arti yang terkandung dalam suatu rangkaian bunyi bersifat arbitrer atau manasuka. Arbitrer atau manasuka berarti tidak terdapat suatu keharusan bahwa suatu rangkaian bunyi tertentu harus mengandung arti yang tertentu pula.

Fungsi bahasa sebagai alat komunikasi yakni, (1) bahasa merupakan akibat yang lebih jauh dari ekspresi diri, (2) komunikasi tidak akan sempurna bila ekspresi diri kita tidak diterima atau dipahami, (3) penggunaan bahasa sebagai alat kandang atau tempat. Bahasa sebagai komunikasi, memiliki tujuan tertentu sarana komunikasi mempunyaii fungsi yaitu agar kita dipahami oleh orang utama bahasa adalah bahwa lain. Jadi dalam hal ini respons pendengar atau lawan komunikan yang menjadi perhatian utama kita. Bahasa sebagai alat komunikasi, bahasa merupakan alat untuk merumuskan maksud kita. Dengan komunikasi, kita dapat menyampaikan semua yang kita rasakan, pikirkan, dan ketahui kepada orang lain.

Dengan komunikasi, kita dapat mempelajari dan mewarisi semua yang pernah dicapai oleh nenek moyang kita dan apa yang telah dicapai oleh orangorang sejaman kita. Bahasa adalah alat untuk berkomunikasi melalui lisan (bahasa primer) dan tulisan (bahasa sekunder). Berkomunikasi melalui lisan (dihasilkan oleh alat ucap manusia), yaitu dalam bentuk symbol bunyi, dimana setiap simbol bunyi memiliki cirri khas tersendiri. Suatu simbol bisa terdengar sama di telinga kita tapi memiliki makna yang sangat jauh berbeda. Misalnya kata 'sarang' dalam bahasa Korea artinya cinta, sedangkan dalam bahasa Indonesia artinya 
Edutech, Tahun 13, Vol.1, No.1, Februari 2014

komunikasi ialah penyampaian pesan atau makna oleh seseorang kepada orang lain.

Keterikatan dan keterkaitan bahasa dengan manusia menyebabkan bahasa tidak tetap dan selalu berubah seiring perubahan kegaiatan manusia dalam kehidupannya di masyarakat. Perubahan bahasa dapat terjadi bukan hanya berupa pengembangan dan perluasan, melainkan berupa kemunduran sejalan dengan perubahan yang dialami masyarakat. Terutama pada penggunaan Fungsi komunikasi pada bahasa asing Sebagai contoh masyarakat Indonesia lebih sering menempel ungkapan "No Smoking" daripada "Dilarang Merokok", "Stop" untuk "berhenti", "Exit" untuk "keluar", “Open House" untuk penerimaan tamu di rumah pada saat lebaran. Jadi bahasa sebagai alat komunikasi tidak hanya dengan satu bahasa melainkan banyak bahasa. (http://dmsprmn.blogspot.com/2012/10 /fungsi-bahasa-sebagai-alat-

komunikasi.html)

Bagi individu atau kelompok "orang Batak" kalau dia berbicara individu minoritas, masalah yang dalam bahasa Batak. Tidak menjadi segera timbul ialah mereka harus menguasai sekurang-kurangnya dua bahasa, yaitu bahasanya sendiri dan bahasa mayoritas, sebelum mereka dapat berfungsi sebagai anggota penuh masyarakat tempat tinggal mereka. Anak kecil yang belajar bahasa ibu cepat menguasai bahasa ibu karena penguasaan terhadap bahasa ibu akan segera menentukan keanggotaanya sebagai anggota masyarakat secara penuh.

Bahasa sebagai ciri pembeda keanggotaan etnik lazim ditentukan di seluruh dunia. Di Jakarta misalnya kita dapatkan sekian banyak bahasa daerah, diantaranya bahasa Jawa, Sunda, Batak, Minang, di samping dialek Jakarta dan bahasa Indonesia. Pada umumnya orang akan menyatakan diri sebagai anggota sesuatu etnik atau suku tertentu dengan ciri penting bahasa ibunya (Sumarsono, 1997:72).

Boleh jadi seseorang akan mengatakan, "Saya orang Batak", karena bahasa ibunya bahasa Batak. Atay seseorang segera mendapat cap 
Edutech, Tahun 13, Vol.1, No.1, Februari 2014

soal, apakah dia lahir di Jakarta atau di Medan. Etnik memperhatikan keterpisahan dan identitas mereka melalui bahsa, meskipun mereka juga mempunyai ciri-ciri lain, misalnya agama, sejarah, kebudayaan adat istiadat, atau mungkin juga fisik.

Bahasa sangat berkaitan dengan budaya. Dalam berkomunikasi tentu penggunaan bahasa juga memperhatikan budaya di mana kita berada. Komunikasi antarbudaya menurut Sumatno (2010: 114) adalah komunikasi antara orang-orang yang berbeda budaya (baik dalam arti ras, etnik, atau perbedaan ekonomi).

Melihat situasinya, kedwibahasaan bukan saja terjadi karena akibat pemakaian bahasa daerah di samping bahasa Indonesia, tetapi juga karena terjadinya interaksi antara masyarakaat suku yang satu dengan suku yang lain. Terutama, dalam lingkungan kehidupan dan ranah-ranah yang telah mengalami medernisasi. Dengan adanya bahasa daerah di samping bahasa Indonesia sudah tentu pemakaian bahasa Indonesia sebagai bahasa negara untuk diri saya sendiri dalam bahasa kurang melembaga (Nababan, 1992: 6). Inggris, dan ketika saya sedang begitu
Terjadinya perpindahan penduduk dari suatu daerah ke daerah lain urbanisasi, transmigrasi, mutasi pegawai, atau alasan perdagangan telah pula membuat timbulnya usaha seseorang untuk mempelajari dan kemudian menguasai bahasa-bahasa daerah lain, demi suksesnya usaha dan tugas masing-masing.

Tidaklah mengherankan apabila di kota besar, kota kecil, bahkan di desadesa, dalam suatu percakapan akan terdengar gejala 'campur bahasa' dan 'alih bahasa' dari bahasa Indonesia ke bahasa daerah atau sebaliknya, yang di sebabkan oleh faktor-faktor dalam situasi berbahasa itu (Nababan: 1992: 7).

Kebiasaan yang dilakukan oleh Lili Rabel-Heymann (Paradis, 1972:220) dalam menguasai bahasa keduanya yakni bahasa Inggris terlihat dalam pernyataan beliau sebagai berikut. Saya berbicara kepada diri saya sendiri dalam bahasa Inggris, saya bermimpi dalam bahasa Inggris, menulis catatan dan memo-memo 
Edutech, Tahun 13, Vol.1, No.1, Februari 2014

terpukul biasanya saya mengeluh dengan bahasa Inggris.

Menurut Kamus Besar Bahasa Indonesia (2005: 146) kebiasaan berasal dari kata biasa yang berarti lazim, seperti sediakala, sudah merupakan hal yang tidak terpisahkan dari kehidupan sehari-hari, sudah seringkali. Jadi kebiasaan adalah sesuatu yang biasa dikerjakan atau pola untuk melakukan tanggapan terhadap situasi tertentu yang dipelajari oleh seorang individu dan yang dilakukannya secara berulang untuk hal yang sama.

Tidak jauh berbeda dengan kenyataan yang terjadi di Indonesia. Seseorang yang ingin mengusai bahasa kedua ia harus membiasakan diri terlebih dahulu. Banyak cara untuk membiasakan diri seperti sering-sering berlatih berbicara sendiri, berinteraksi dengan masyarakat setempat. Namun, dalam situasi tertentu yang bersifat informal, masyarakat pemakai bahasa, seperti pedagang masih cenderung menggunakan bahasa daerah mereka. Situasi yang bersifat informal itu misalnya, pada saat para penutur saling berbicara dengan orang-orang yang sesuku dan antara orang tua dengan orang tua. Situasi lain seperti, pedagang yang berasal dari suatu daerah berdagang ke daerah lain, maka mereka akan berusaha untuk dapat mengusai bahasa daerah berdagang tersebut.

Misalnya, orang Padang datang ke Bandung dengan tujuan berdagang. Mereka akan berusaha untuk dapat menguasai bahasa setempat yakni bahasa Sunda. Pengusaan yang dimaksud disini dapat dilakukan dengan kebiasaan dalam berkomunikasi dengan masyarakat setempat. Apabila telah terbiasa berkomunikasi maka kita akan cepat mengusai bahasa daerah yang menjadi tempat usaha kita. Tujuannya tidak hanya lancar berkomunikasi tetapi juga dapat mengembangkan usaha di daerah lain yang bukan daerah asal kita.

\section{B. HASIL DAN PEMBAHASAN}

1. Deskripsi Data dan Analisis Data

Pada penelitian ini peneliti mengambil data di toko Rock Stuff Asesoris tepatnya di 
Edutech, Tahun 13, Vol.1, No.1, Februari 2014

Parahyangan Plaza Jalan Dalem Kaum, Alun-alun Bandung. Objek penelitian ini yakni para penjual/ pelayan toko Rock Stuff Asesoris. Data diambil dari hasil terjadinya tawar menawar antara penjual dan pembeli yang masuk ke dalam toko Rock Stuff Asesoris. Data ini berupa ujaran yang disampaikan oleh baik penjual maupun pembeli yang dijadikan objek penelitian.

Penjual/ pelayan yang menjadi objek penelitian ini akan dilibatkan hanya tiga orang saja karena saat peneliti mengadakan observasi situasi tawar-menawar sampai pembeli selesai membeli terjadi percakapan antara pembeli dan tiga orang pelayan toko tersebut. Pembeli itu adalah orang Bandung tepat tinggal di Lembang. Sedangkan ketiga pelayan toko yang bernama Rizki, Tomi dan Eva yang daerah asalnya berbeda-beda. Rizki yang berasal dari Padang baru mengenal bahasa Sunda saat pertama kali ia datang ke Bandung Rizki datang ke Bandung tahun 2005. Sekarang ini ia telah bisa berkomunikasi dengan menggunakan bahasa Sunda.

Tomi sebenarnya asli Padang, tetapi sejak kecil di bawa oleh orang tuanya merantau ke Tangerang. Saat masuk SMP ia di bawa pindah oleh orang tuanya ke Serang sampai awal tahun 2007 sebelum ia datang ke Bandung. Sedangkan Eva berasal dari Bandung maka ia dapat dengan lancar menggunakan bahasa Sunda.

Data yang dikumpulkan berupa hasil ujaran dari interaksi antara Rizki, Tomi, dan Eva dengan pembeli di toko Rock Stuff Asesoris. Data yang dikumpulkan dilakukan dengan cara pengamatan (observasi langsung).

\section{Hasil Analisis Data}


Edutech, Tahun 13, Vol.1, No.1, Februari 2014

Objek dari penelitian ini ada tiga orang yaitu Rizki, Tomi, dan Eva. Rizki yang berasal dari Padang dapat berinteraksi dengan pembeli atau pengunjung toko dengan menggunakan bahasa Sunda. Tomi yang juga berasal dari Padang tetapi karena sejak kecil sudah berada di daerah Serang yang mana lingkungan disana sebahagian juga menggunakan bahasa Sunda. Jadi Tomi tidak mengalami kesulitan saat berada di Bandung yaitu sebagai penjual asesoris di toko Rock Stuff. Tomi dapat berinteraksi dengan pembeli atau pengunjung menggunakan bahasa Sunda dengan lancar. Sedangkan Eva yang memang berasal dari Bandung tentu tidak akan mengalami kesulitan dalam berinteraksi.

Bahasa yang dikuasai oleh Rizki ada tiga yaitu, bahasa Minang, bahasa Sunda, dan bahasa Daerah. Tomi mengusai bahasa Minang, bahasa Sunda, dan bahasa Indonesia. Tetapi berbeda dengan Eva yang hanya menguasai dua bahasa yaitu bahasa Sunda dan bahasa Indonesia.

Objek penelitian yang bernama Rizki dapat dikatakan bilingual. Kenapa? Karena Rizki biasa menggunakan bahasa Sunda dan bahasa Minang. Bahasa Sunda ini digunakan saat ia berada di lingkungan yang berbahasa Sunda juga seperti, di toko, dengan teman-teman yang memang berasal dari Bandung. Sedangkan bahasa Minang hanya digunakan dengan keluarga yang juga berasal dari Padang juga. Rizki selalu membiasakan diri menggunakan bahasa Sunda untuk berinteraksi dengna orang lain. Tujuan utama kebiasaan yang dilakukan oleh Rizki ini yakni untuk memajukan usaha penjualan asesoris di toko Rock Stuff tersebut. Tujuan lain adalah agar lancar dan dapat 
Edutech, Tahun 13, Vol.1, No.1, Februari 2014

berinteraksi dengan teman sebaya dengan lancar tanpa hambatan.

Bahasa Sunda yang ia gunakan cukup kaya dengan perbendaharaan kata yang ia kuasai karena biasa menggunakannya. Situasi lain yang menjadi kebiasaan Rizki menggunakan bahasa Sunda adalah saat marah dan mengumpat orang lain. Misalnya, ada pengunjung yang masuk ke toko setelah begitu lama melihat-lihat barangbarang di toko ternyata ia tidak membeli. Nah, saat itulah kebiasaan penggunaan bahasa kedua (bahasa Sunda) Rizki kelihatan karena ia mengumpat orang yang tidak jadi membeli tadi.

Kebiasaan penggunaan bahasa kedua (bahasa Sunda) yang dilakukan oleh Rizki terlihat juga saat ia marah. Contohnya, suatu saat ada lima orang siswa SMA yang mengunjungi toko Rock Stuff tersebut. Setelah lama di dalam toko ternyata siswa-siswa tersebut hanya bertanya tentang barang yang tidak ada di dalam toko. Setelah siswa-siswa tadi keluar dari toko, ada salah seorang pelayan toko juga yang melihat salah seorang dari siswa tadi mengambil barang tanpa memberitahu atau membeli. Rizki langsung naik darah dan marah. Siswa-siswa tersebut dikejarnya hingga pintu lift. Sambil marah-marah Rizki menggunakan bahasa Sunda kepada siswa itu.

Alasan Rizki menggunakan bahasa Sunda saat marah tersebut supaya siswa itu memahami dan mengerti kemarahan yang dilakukan Rizki. Tetapi misalnya saja Rizki menggunakan bahasa Minang, maka siswa-siswa tersebut tidak akan paham apa yang telah Rizki perbuat terhadap temannya.

Tidak berbeda dengan Tomi. Saat kejadian yang 
Edutech, Tahun 13, Vol.1, No.1, Februari 2014

dialami Rizki di atas, ternyata Tomi ikut dalam kejadian yang dialami Rizki. Tomi juga menggunakan bahasa Sunda saat marah-marah ke siswasiswa tadi. Sedangkan Eva tentu juga seperti itu karena memang Eva selalu menggunakan bahasa Sunda dalam kehidupan sehariharinya.

\section{Pembahasan Hasil Analisis}

Kebiasaan menggunakan
bahasa kedua sangat
mendukung kita dalam hal
apapun. Baik dari interaksi
dengan orang lain maupun
untuk memengembangkan dan
memajukan usaha kita di daerah
orang lain. Kebiasaan
menggunakan bahasa kedua
dapat dilakukan setiap waktu,
seperti selalu membiasakan diri
menggunakan bahasa kedua
kepada diri sendiri. Berani
mengungkapkan walaupun
salah. Dari kebiasaan itu akan
selalu tertanam dalam hati kita.
Seperti hasil interaksi Rizki,
Tomi, Eva dengan salah

seorang pengunjung atau pembeli yang berasal dari Lembang Bandung.

Rizki: "Mangga a' ditingal."

Pembeli: "Hatur nuhun."

Rizki: "Bade milari naon a'."

Pembeli: "Bade ningalan heula."

Pembeli: 'Punten a' mun kupluk rasta sabaraha salusinna nu ukuran ieu?"

Rizki: ”Mun ieu salunsinna Rp. 60.000. Bade nyandak sabaraha lusin a'?"

Pembeli: "nya, abi bade nyandak 5 lusin."

Rizki: "Nu sanesna naon deui?" Pembeli: "Abi bade nyandak sarung handphone 10 model, 3 lusin per modelna, bisa kan?"

Rizki: "Tom, punten pang nyandakeun sarung handphone nu ieu di gudang."

Tomi: "Sabaraha lusin, bade aya nu dicandak nu lainna, ngarah sakalian."

Rizki: "Oh ya, sakalian tas paha nu model ieu."

Beberapa saat kemudian. 
Edutech, Tahun 13, Vol.1, No.1, Februari 2014

Tomi: "Eva, konci gudang dimana? Ningali teu?"

Eva: "Mun teu salah tadi Eva ningal di dekeut gantungan anting."

Tomi: "Oh ya aya."

Rizki: "Tom pang nuliskeun notana, abi bade ngecek heula barangna tos cukup atau can."

Tomi: "Nya."

Eva: "Tomi keur nulis nota nu saha?"

Tomi: : ieu nota nu orang Lembang, tu jalmina dipayun."

Eva:"Ooo.."

Tomi: "Va pang masihkeun plastik jeung dus dompet keur ieu."

Eva, "Iya, sabaraha hiji?"

Tomi: "Tanyakeun ka Rizki, abi can nulis notana."

Rizki: "A' ieu barangna tos beres di pak, ieu notana."

Pembeli: "Oh ya, hatur nuhun."

Percakapan dalam bahasa

Indonesia dapat di lihat di bawah ini.

Rizki: "Silahkan a' dilihat-lihat dulu."
Pembeli: "Oh ya, makasih."

Rizki: "Mau cari apa a'."

Pembeli: "Mau lihat-lihat dulu."

Pembeli: "Maaf a' kalau kupluk rasta berapa 1 lusin yang ukuran ini?"

Rizki: "Kalau yang itu 1 lusinnya Rp. 60.000. Mau ngambil berapa lusin a'?

Pembeli: "Iya, saya mau ambil 5 lusin."

Rizki: "Yang lain apa ada lagi?" Pembeli: "Saya mau minta sarung handphone 10 model, 3 lusin per modelnya, bisa kan?" Beberapa saat kemudian.

Rizki: "Tom tolong ambilkan sarung handphone yang ini digudang."

Tomi: "Berapa lusin, apa ada yang mau diambil yang lainnya, biar sekalian."

Rizki: "Oh ya, sekalian tas paha yang model ini”.

Beberapa saat kemudian.

Tomi: "Eva, kunci gudang dimana? Liat gak?"

Eva: "Kalau gak salah tadi Eva liat di dekat gantungan anting." 
Edutech, Tahun 13, Vol.1, No.1, Februari 2014

Tomi: Oh ya ada."

Rizki: "Tom tolong bikin notanya, aku mau cek dulu barangnya apa sudah cukup." Tomi: "Iya."

Eva: "Tomi lagi bikin nota buat siapa?"

Tomi: "Ini nota untuk orang Lembang, tuh orangnya di depan."

Eva:"Oo..."

Tomi: "Va tolong dikasih plastik ama dus dompet buat ini."

Eva: "Iya, berapa banyak?"

Tomi: "Coba tanya dulu ma Rizki,aku belum tulis notanya." Rizki: "A' ini barangnya udah selesai di pak, ini notanya." Pembeli: "Oh ya, makasih."

Dilihat dari percakapan di atas dapat diketahui bahwa di toko ini selalu membudayakan penggunaan bahasa kedua yakni bahasa Sunda karena kebanyakan pembelinya berasal dari Bandung. Rizki dan Tomi yang berasal dari Padang sudah membiasakan diri untuk menggunakan bahasa Sunda untuk kelancaran usaha di toko ini.

\section{SIMPULAN}

Hasil penelitian ini sangat menarik bagi peneliti karena yang menjadi pembahasannya cukup menantang yaitu tentang kebiasaan menggunakan bahasa kedua oleh penjual yang berasal dari Padang di toko Rock Stuff Asesoris. Mereka selalu berusaha melayani pembeli yang berasal dari Bandung dengan menggunakan bahasa Sunda. Semua itu demi kelancaran dan keakraban antara penjual dan pembeli. Maka, hasil penelitian ini dapat diambil kesimpulan sebagai berikut: (1) kebiasaan menggunakan bahasa kedua dapat dimulai dari kebiasaan sendiri, seperti berbicara sendiri, marah sendiri, mengeluh dengan menggunakan bahasa kedua; (2) kebiasaan menggunakan bahasa kedua sangat berguna untuk kelancaran usaha dimana kita berada; (3) kebiasaan menggunakan bahasa kedua sangat dekat dengan situasi yang kita alami, seperti marah, mengumpat, dan mengeluh; dan (4) kebiasaan menggunakan bahasa kedua dapat 
Edutech, Tahun 13, Vol.1, No.1, Februari 2014

dilakukan setiap saat karena apabila rajin mempraktekkannya maka akan lancar menggunakannya.

\section{DAFTAR PUSTAKA}

Effendy, Onong Uchjana. 2011. Ilmu Komunikasi. Rosdakarya.

Permana, Dimas. 2012. Fungsi Bahasa sebagai Alat Komunikasi. Sumber Online di http://dmsprmn.blogspot.com/20 12/10/fungsi-bahasa-sebagai-alatkomunikasi.html [diakses 10

September 2013]

Pusat Bahasa. 2005. Kamus Besar Bahasa Indonesia. Jakarta: Balai Pustaka Kementerian Pendidikan Nasional.

Nababan, dkk. 1992. Survei Kedwibahasaan Di Indonesia.
Jakarta: Pusat Pembinaan dan Pengembangan Bahasa, Departemen Pendidikan dan Kebudayaan.

Paradis, Michel. 1972. Aspects of Bilingualism. Colombia: Hornbeam Press, Incorporated.

Pusat Bahasa Depdiknas. 1995. Kamus Besar Bahasa Indonesia. Jakarta: Balai Pustaka.

Sumarsono. 2007. Sosiolinguistik. Yogyakarta: Pustaka Pelajar.

Suwatno. 2010. Komunikasi Bisnis. Bandung: Rizqi Press.

Rusyana, Yus. 1989. Perihal Kedwibahasaan (Bilinguaisme). Jakarta: Departemen Pendidikan dan Kebudayaan, Direktorat Jenderal Pendidikan Tinggi, Proyek Pengembangan Lembaga Pendidikan Tenaga Kependidikan. 